\title{
Technology, ritual and Anglo-Saxon agriculture: the biography of a plough coulter from Lyminge, Kent
}

\author{
Gabor Thomas ${ }^{1}$, Gerry McDonnell ${ }^{2}$, John Merkel ${ }^{3} \&$ Peter Marshall $^{4}$
}

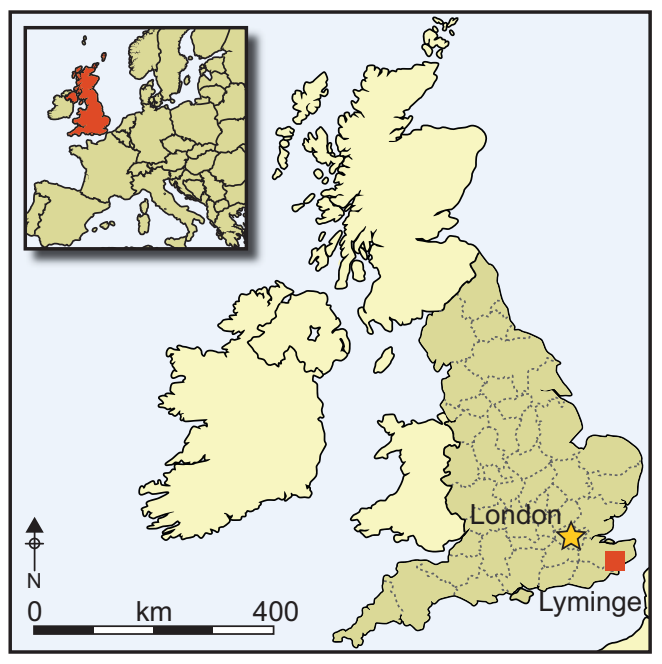

The discovery of an unusual early medieval plough coulter in a well-dated AngloSaxon settlement context in Kent suggests that continentally derived technology was in use in this powerful kingdom centuries before heavy ploughs were first depicted in Late Saxon manuscripts. The substantial investment required to manufacture the coulter, the significant damage and wear that it sustained during use and the circumstances of its ultimate ritual deposition are explored. Investigative conservation, high-resolution recording and metallographic analysis illuminate the form, function and use-life of the coulter. An examination of the deposition contexts of plough-irons in early medieval northern Europe sheds important new light on the ritual actions of plough symbolism in an age of religious hybridity and transformation.

Keywords: England, Anglo-Saxon, plough, coulter, iron, technology, ritual, object biography

\section{Introduction}

The transition from the ard to the heavy plough dominates narratives of post-Roman agricultural intensification in medieval Europe. According to the maximalist view, the assimilation of this new technology both increased food production-a prerequisite of population expansion - and triggered the wholesale reconfiguration of medieval landscapes, including the internal structure of settlements (Duby 1978; Banham \& Faith 2014: 50-57).

While the adoption of the heavy plough is agreed to be crucial to the development of the medieval rural economy, the timing of its introduction across early medieval Europe is a

\footnotetext{
1 Department of Archaeology, University of Reading, Whiteknights, Reading RG6 6AB, UK (Email: gabor.thomas@reading.ac.uk)

Gerry McDonnell Archaeometals, The Oxford, 50 Hereford Street, Presteigne, Powys LD8 2AT, UK

UCL Institute of Archaeology, 31-34 Gordon Square, London WC1H OPY, UK

English Heritage Scientific Dating Team, 1 Waterhouse Square, 138-142 Holborn, London EC1N 2ST, UK
}

(C) Antiquity Publications Ltd, 2016. This is an Open Access article, distributed under the terms of the Creative Commons Attribution licence (http://creativecommons.org/licenses/by/4.0/), which permits unrestricted re-use, distribution, and reproduction in any medium, provided the original work is properly cited. 
subject of intense debate (Fowler 2002: 308-10). On account of their durability, shares and coulters (a vertically mounted blade that slices the soil ahead of the plough share) have been central to this discourse because in most regions they constitute the only surviving vestiges of early medieval tillage implements themselves. There are, however, complexities in using these survivals as a basis for interpretation, not least because their discovery is dependent upon culturally distinct modes of deposition (e.g. hoards, burials), resulting in inconsistent geographic and temporal distribution (Klápště \& Jaubert 2007: 97-100). Moreover, any particular form of share or coulter can be interpreted in multiple ways, often revealing clear divergences of view on how tillage implements were actually used and the technological evolution of the prehistoric ard into the heavy plough (White 1962: 41-43; Klápště 1998; Fowler 2002: 182-86).

Given these problems, it is perhaps unsurprising that archaeologists have failed to exploit the full interpretative potential of these artefacts. While explanatory frameworks now allow for greater complexity and regional diversity in the transition from ard to plough in early medieval Europe-with significant chronological overlap between the two (Fowler 2002: 183-202; Klápště \& Jaubert 2007: 97-98)—the underlying approach remains essentially the same: descriptive typology supporting diffusionist statements on cultural origins and influence. With notable exceptions (e.g. Lerche 1994), much less investment has been made in addressing the use-life and social biography of these objects through detailed technical analyses and consideration of depositional context (Jones 2002; Joy 2009: 545).

This paper evaluates the significance of a vital new find: an early medieval plough coulter from Lyminge, Kent - the only example of its type from a well-dated Anglo-Saxon settlement context. We reconsider the development of Anglo-Saxon plough technology in light of this discovery, but take interpretation to a deeper level by adopting a biographical approach. Investigative conservation, high-resolution recording and metallographic analysis are integrated to explore the coulter's manufacture and use, while its find context is used to reinterpret the meaning behind the deposition of plough-irons in early medieval northern Europe.

\section{Archaeological background}

The coulter was discovered in 2010 during an archaeological project examining the early medieval origins of the modern-day village of Lyminge, a documented Anglo-Saxon monastery established on the site of an earlier royal centre. The excavation of areas surrounding the churchyard has produced the first high-resolution settlement sequence for a royal centre in early medieval Kent, with high-status occupation spanning the later fifthlater ninth centuries $\mathrm{AD}$, represented by monumental timber architecture and exceptionally rich cultural and bioarchaeological assemblages. This detailed site narrative provides a new platform for investigating how the earliest generation of such sites of royal residence evolved in relation to wider socio-political processes, including the conversion to Christianity (Thomas \& Knox 2012; Thomas 2013).

The Anglo-Saxon settlement sequence at Lyminge comprises two chronologically successive sites. The plough coulter belongs to the earlier of these sites, located in the lowerlying reaches of the present village beside the source of the River Nailbourne (Figure 1). 
Gabor Thomas et al.

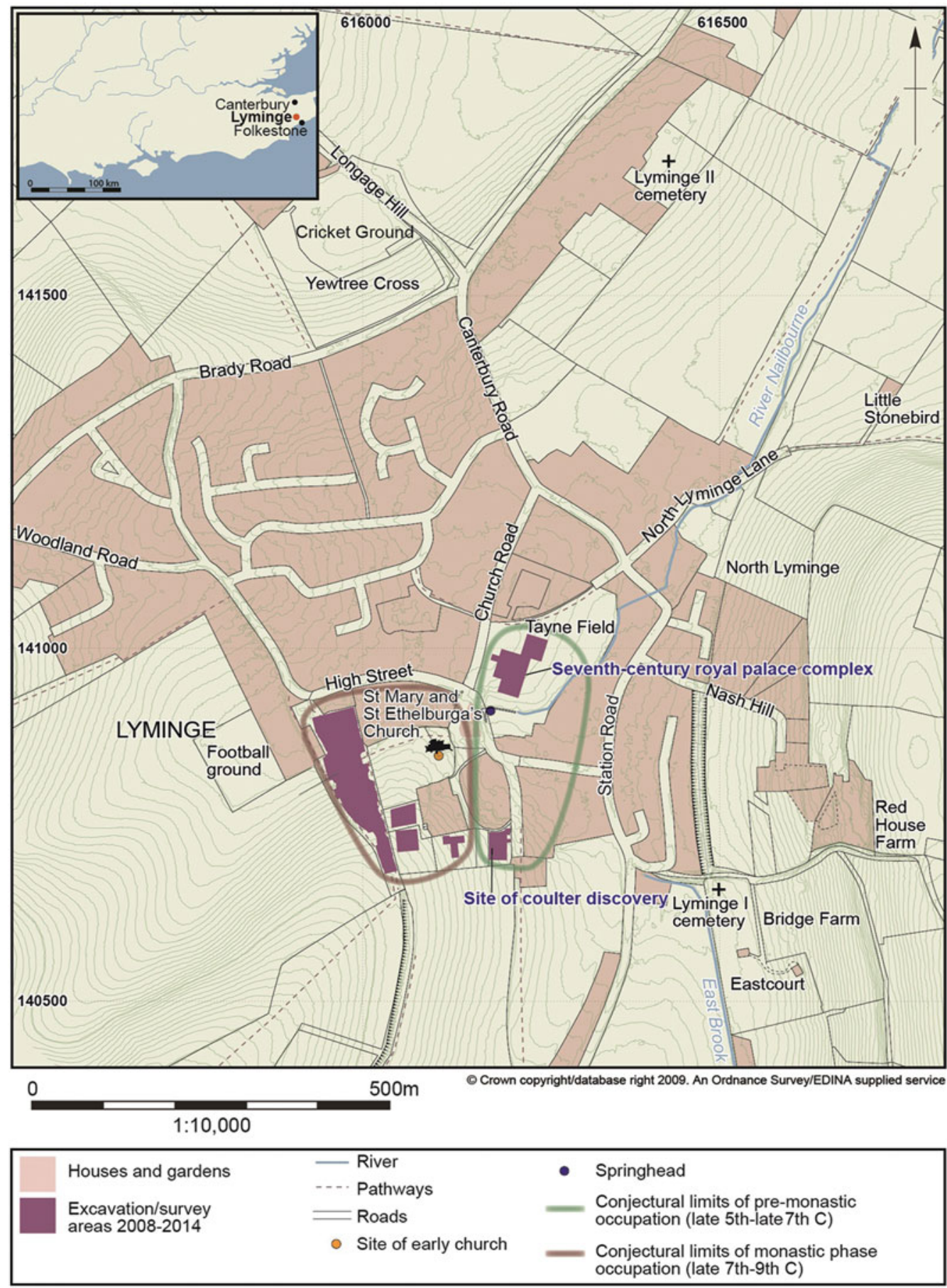

Figure 1. Location of excavations 2008-2014 shown in relation to approximate extent of the two chronologically consecutive Anglo-Saxon settlement foci.

(C) Antiquity Publications Ltd, 2016 
Table 1. Radiocarbon samples SUERC-35927/35929; the radiocarbon determinations have been calibrated with data from Reimer et al. (2009) using OxCal (v4.1) (Bronk Ramsey 2009), with date ranges calculated according to the maximum intercept method (Stuiver $\&$ Reimer 1986).

\begin{tabular}{|c|c|c|c|c|c|}
\hline Lab. no. & Material & $\begin{array}{l}\text { Radiocarbon } \\
\text { age (BP) }\end{array}$ & $\delta^{13} \mathrm{C}(\%)$ & $\begin{array}{l}\text { Calibrated date } \\
\text { range }(95 \% \\
\text { confidence })\end{array}$ & $\begin{array}{c}\text { Posterior } \\
\text { density } \\
\text { estimate } \\
\text { (95\% probability) }\end{array}$ \\
\hline $\begin{array}{c}\text { SUERC- } \\
35927\end{array}$ & $\begin{array}{l}\text { animal bone, } \\
\text { juvenile pig tibia } \\
\text { (left) from an } \\
\text { articulated } \\
\text { animal disposal }\end{array}$ & $1444 \pm 25$ & -21.4 & cal AD 565-655 & cal AD 595-635 \\
\hline $\begin{array}{r}\text { SUERC- } \\
35929\end{array}$ & $\begin{array}{l}\text { animal bone, cow } \\
\text { (young adult) } \\
\text { mandible } \\
\text { including } \\
\text { mandibular M3 } \\
\text { from an } \\
\text { articulated } \\
\text { animal }\end{array}$ & $1448 \pm 24$ & -21.8 & $\mathrm{cal} \mathrm{AD} \mathrm{565-655}$ & cal AD 570-645 \\
\hline
\end{tabular}

Established by the end of the fifth century, this primary habitation passed through several phases of development before an abrupt end during the late seventh or early eighth century, when the settlement refocused around the new monastic community. The most notable event in this early phase was the construction of a suite of monumental timber halls sharing close architectural affinities with other excavated seventh-century Anglo-Saxon royal residences, e.g. Yeavering (Hope-Taylor 1977).

\section{Deposition and date}

The specific context of discovery was SFB 1, one of seven sunken-featured buildings (Grubenhäuser) widely dispersed across the early Anglo-Saxon settlement. The excavated footprint of the building comprised a sub-rectangular cut, measuring $4.7 \times 3.6 \times 0.5 \mathrm{~m}$, with a pair of internal post-holes marking the position of axially aligned roof supports (Hamerow 2012: 53-66). Micromorphology and geochemical analysis show that following abandonment, as is common for such structures, the pit was rapidly infilled with domestic refuse (Tipper 2004).

The coulter was found at the base of the pit adjacent to its south-eastern corner, sealed below the earliest episode of dumping; it had been deposited in isolation without a container (Figures $2 \& 3$ ). Its deposition can be confidently attributed to the first half of the seventh century cal $\mathrm{AD}$ on the basis of the chronological modelling of a terminus ante quem from the earliest of the overlying dumps, and a terminus post quem from a context associated with the abandonment of a post-hole building truncated by SFB 1 (Figure 4; Table 1). 
Gabor Thomas et al.
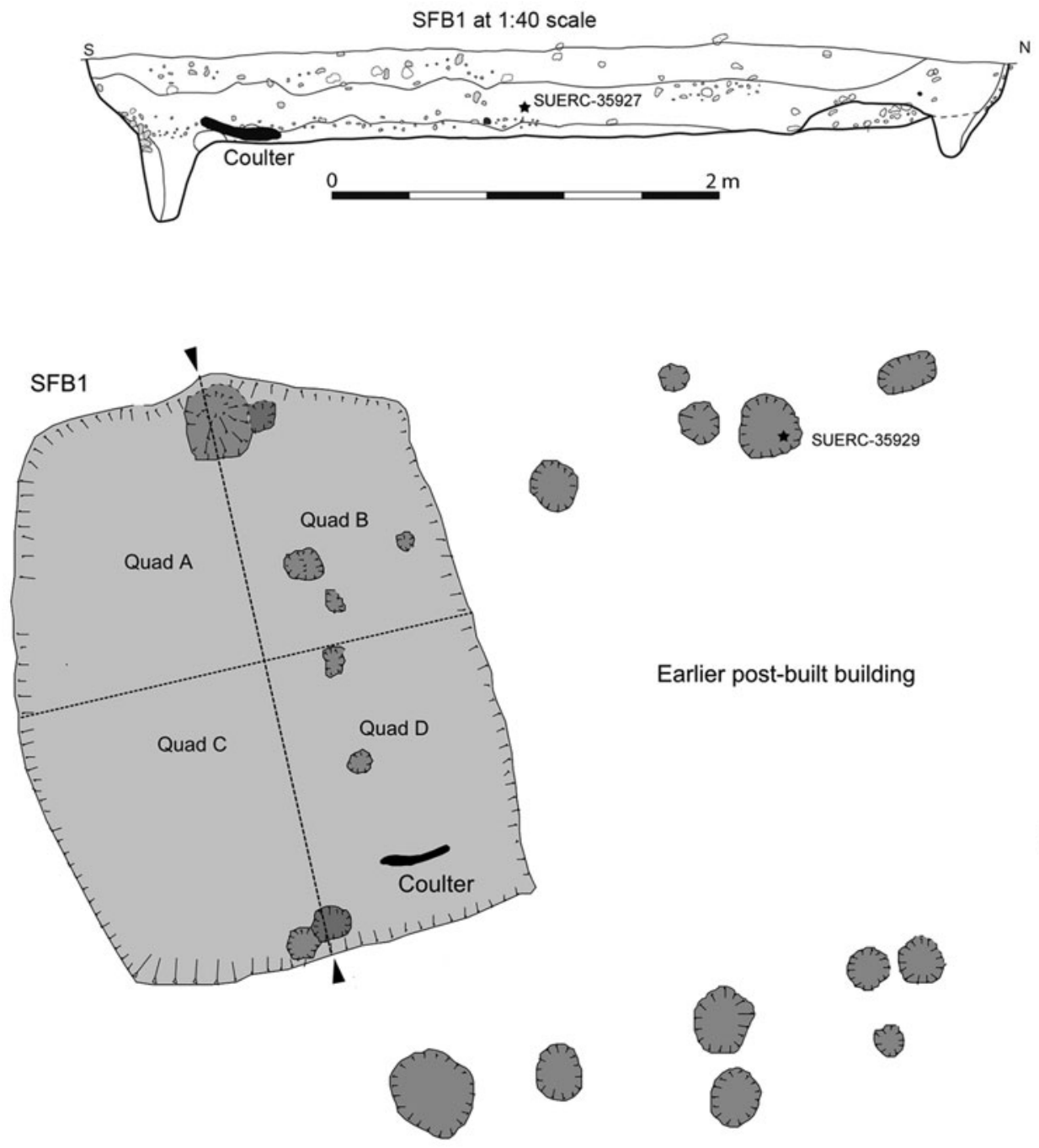

Earlier post-built building
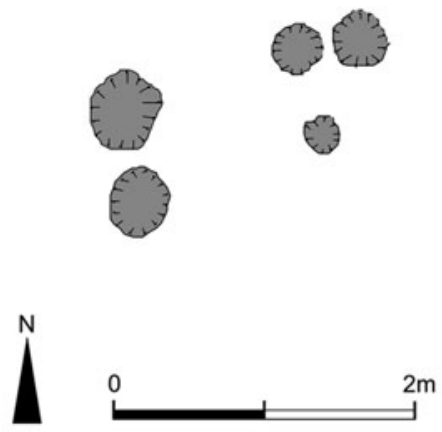

Figure 2. Plan and section of SFB1, showing the locations of the plough coulter, radiocarbon samples and the underlying post-built timber structure.

\section{Form and typology}

Weighing $5.6 \mathrm{~kg}$ and measuring $680 \mathrm{~mm}$ in length, the Lyminge coulter is, by a considerable margin, the most substantial agricultural implement yet discovered from early Anglo-Saxon England. The coulter comprises two elements: a blade measuring $260 \mathrm{~mm}$ long and $94 \mathrm{~mm}$ at its widest point, featuring a curved back and a straight cutting edge angled inwards at the

(C) Antiquity Publications Ltd, 2016 


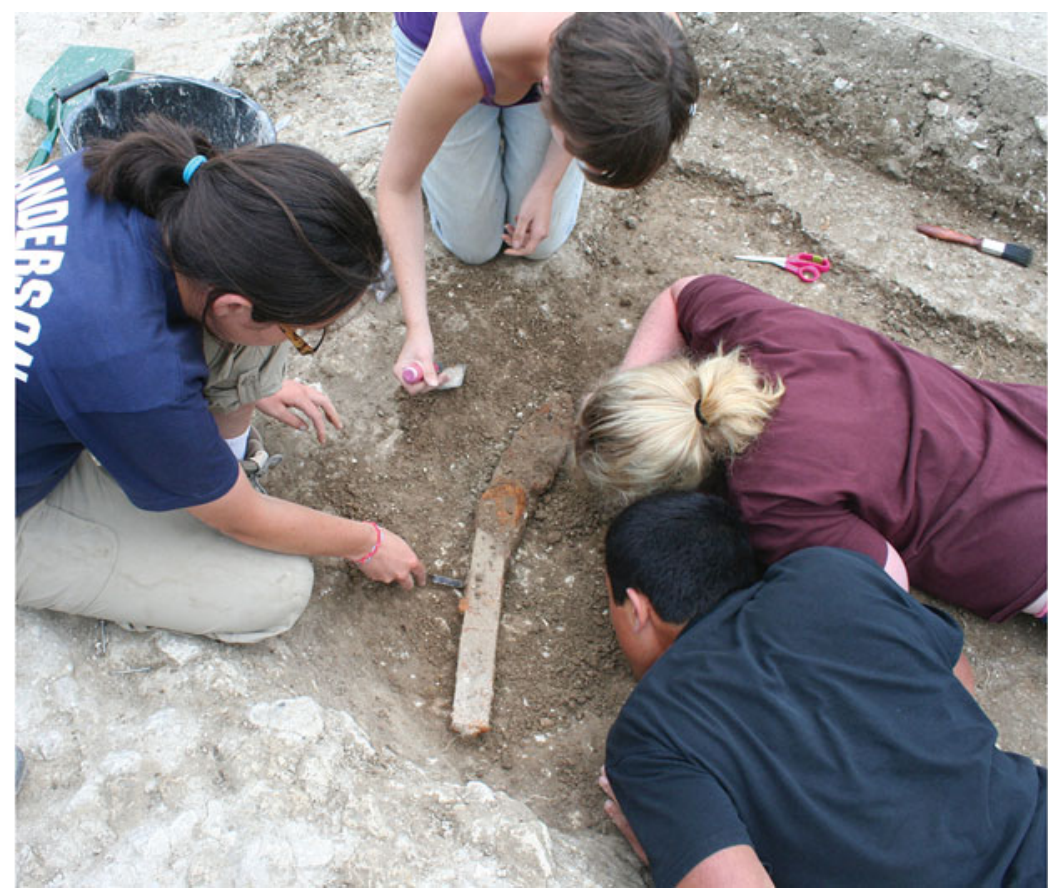

Figure 3. The coulter during the final stages of excavation prior to lifting and recovery.

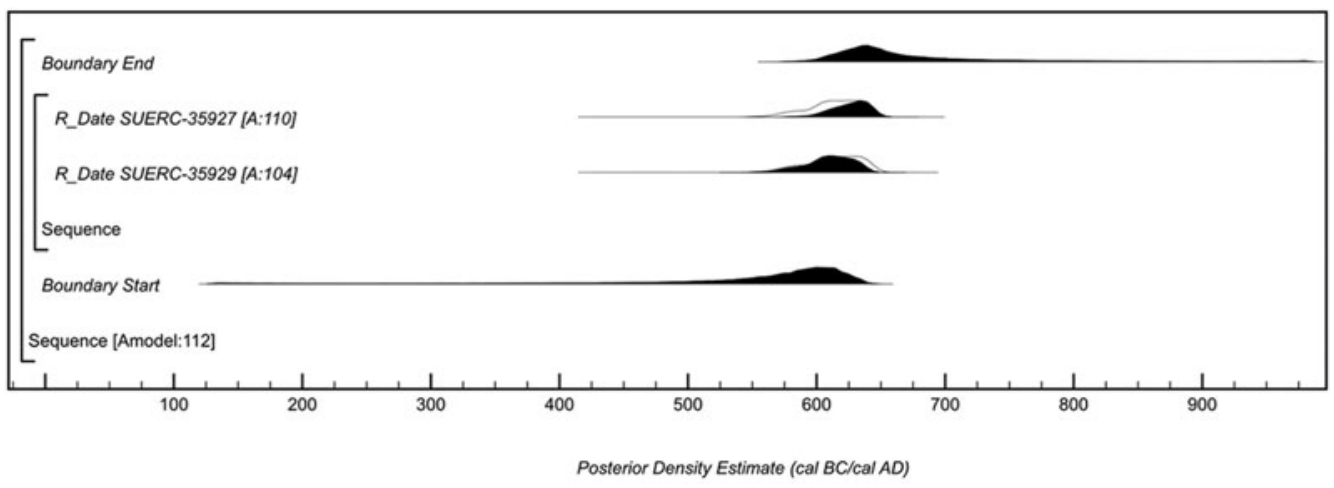

Figure 4. Probability distributions of dates from Lyminge based upon simulation using OxCal (v4.1) (Bronk Ramsey 2009).

back, and terminating in a rounded tip at the front; and a straight, rectangular-sectioned shaft measuring $420 \mathrm{~mm}$ in length (Figures $5 \& 6$ ).

The coulter is over $100 \mathrm{~mm}$ longer than the next largest from Anglo-Saxon England (Scraptoft, Leicestershire: Leahy 2013), and is exceeded in size only by the very largest examples known from the Romano-British and post-medieval periods (Rees 1979: 60; Lerche 1994: 228, fig. 9.53; Leahy 2013: 224-25). 


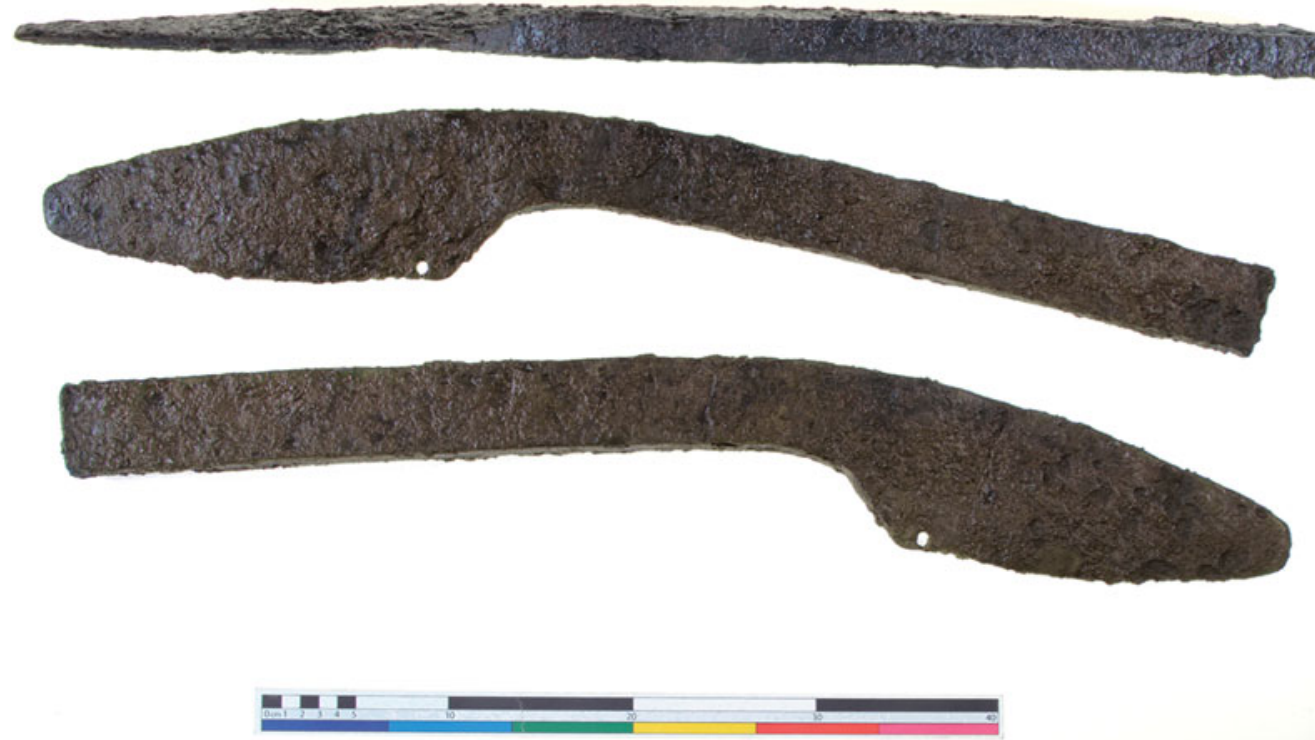

Figure 5. The coulter after investigative conservation and refilling of metallographic sections.

X-radiography and investigative conservation revealed a second feature of diagnostic relevance: an $8 \mathrm{~mm}$-diameter circular perforation adjacent to the cutting edge of the blade (Figure 5). Although unparalleled on other early medieval coulters from the British Isles, this feature is attested on the Continent during this period, and may have facilitated the connection of a chain between the plough-beam and the coulter (Henning 2009: 153-56).

\section{Manufacture and use}

Visible weld-lines, also delineated metallographically by lines of slag inclusions, indicate that at least three billets (forgeable metal bars produced by refining smelted iron ore) were used to forge the coulter (Figure 7). A clear division in the metallography of the shaft raises the potential of a fourth billet rendered invisible by a near perfect weld that had achieved crystal intergrowth between the two pieces of metal. If the latter is taken into account, then the coulter was originally forged from four equally sized billets, each weighing around $1400 \mathrm{~g}$.

Each of the constituent billets was manufactured using different combinations of the three main alloy types present in early iron metallurgy: ferritic iron, phosphoric iron and steel. Metallographic analysis has shown that such piled or banded structures represent a standard feature of Anglo-Saxon ironwork, either the result of deliberate manufacture, or accidental generation during the smelting or primary smithing process (Tylecote \& Gilmour 1986; McDonnell 1989). The same ambiguity holds for the Lyminge coulter, particularly in relation to the more structurally complex blade and shoulder sections, where up to four bands are present (Table 2; Figure $8 \mathrm{~A} \& \mathrm{~B}$ ).

(C) Antiquity Publications Ltd, 2016 


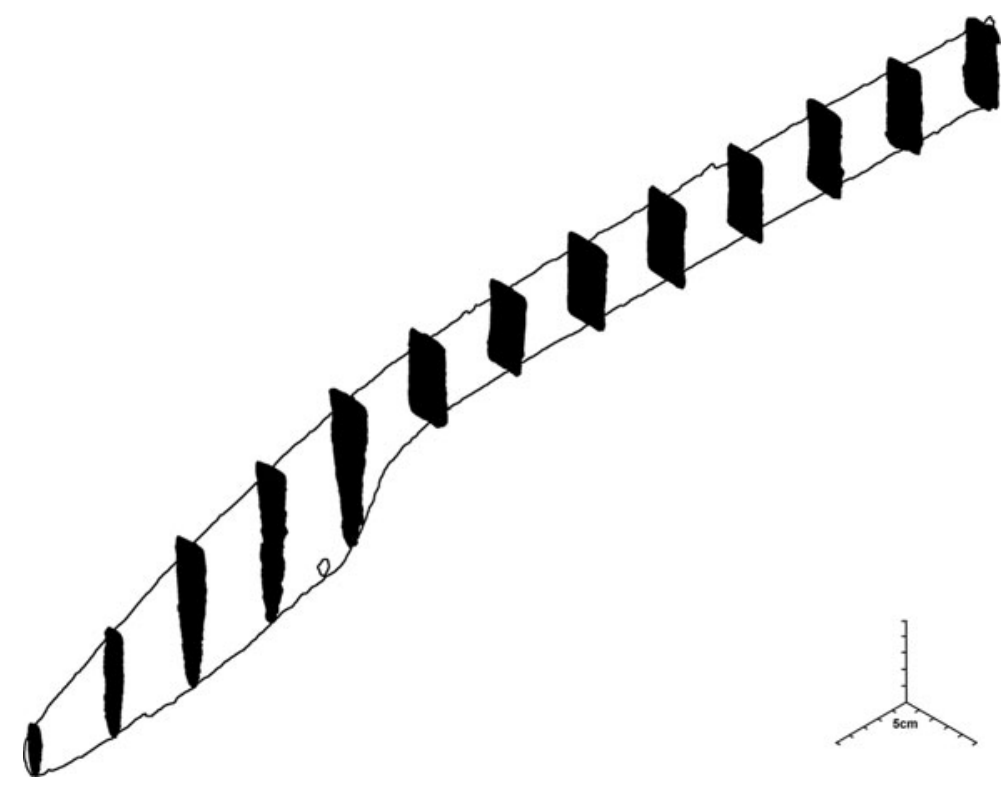

Figure 6. Isometric profile through the coulter generated by laser scanning using a Romer Absolute 7320 SI Arm Scanner and Geomagic Studio 2013 software.

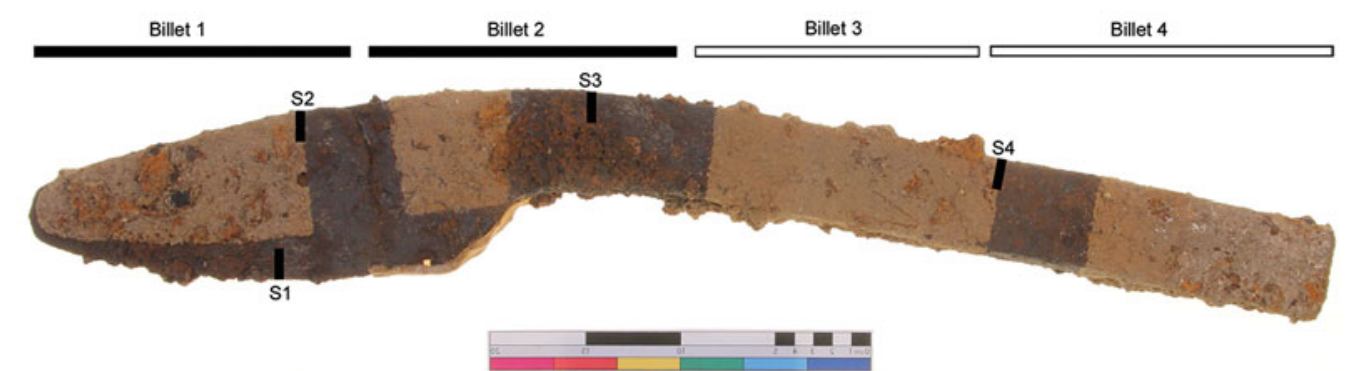

Figure 7. Locations of metallographic sections and the iron billets used in the construction of the coulter; billets 1-2, marked in solid boxes, are based upon visible weld-lines, whereas billets 3-4 (open boxes) are inferred from metallographic analysis.

The manufacture of the coulter represented a considerable investment of raw materials, labour and resources. The four billets would have been individually forged from blooms, each derived from a separate smelting event. The final forming of the coulter probably required three smiths and a bellows operator: one smith to hold the separate bars, another to wield the heavy hammer, both under the direction of a master smith. This is far beyond the capacity of a typical early medieval smithy with a single artisan, but it is otherwise consistent with archaeological and historical evidence demonstrating Lyminge's role as an important Anglo-Saxon centre of iron production (McDonnell et al. 2012; Thomas 2013: 131).

Clear signs of wear are evident on the coulter. The two overlapping surfaces of metal forming the scarf-weld in the central portion of the blade have sheered apart under stress,

(C) Antiquity Publications Ltd, 2016 
Table 2. Summary of microstructure of the coulter revealed by each of the metallographic sections.

\begin{tabular}{|c|c|c|c|c|}
\hline Billet/section no. & Component 1 & Component 2 & Component 3 & Structure \\
\hline 1: sections $1 \& 2$ & ferrite & phosphoric & $\begin{array}{l}\text { ferrite plus } \\
\text { carbide }\end{array}$ & $\begin{array}{l}\text { banded structure with } \\
\text { components present in } \\
\text { four alternating bands at } \\
\text { the cutting edge and } \\
\text { back of blade }\end{array}$ \\
\hline 2: section 3 & ferrite & $\begin{array}{l}\text { ferrite/phosphoric } \\
\text { bands }\end{array}$ & $\begin{array}{l}\text { high carbon } \\
\text { steel }\end{array}$ & $\begin{array}{l}\text { central band of high } \\
\text { carbon steel flanked on } \\
\text { one side by a ferritic } \\
\text { band and on the other } \\
\text { by a strip that contains } \\
\text { numerous thinner bands } \\
\text { of ferritic and } \\
\text { phosphoric iron }\end{array}$ \\
\hline 3: section 4 & ferrite & $\begin{array}{l}\text { ferrite and } \\
\text { phosphoric }\end{array}$ & & $\begin{array}{l}\text { ferritic and phosphoric } \\
\text { iron with a carbon zone } \\
\text { at the top of the section } \\
\text { resulting from carbon } \\
\text { diffusion }\end{array}$ \\
\hline 4: section 4 & ferrite & & & $\begin{array}{l}\text { ferrite and low carbon } \\
\text { microstructure }\end{array}$ \\
\hline
\end{tabular}

while further stress cracking is evident at the shoulder (Figures $9 \& 10$ ). Metallographic examination reveals that the latter occurred at a natural point of weakness: the interface between the brittle core of high carbon steel and the flanking bars of more malleable ferritic/phosphoric iron (Figure 8D). A second indication of wear is the position of the perforation close to the cutting edge of the blade. This precarious position is best explained as a consequence of blade wear from regular use, as documented by the experimental use of replica medieval ploughs (Lerche 1994: 187-89). The weight of evidence suggests that, when deposited, the coulter was no longer capable of fulfilling its original purpose.

\section{Discussion}

\section{Implications for Anglo-Saxon plough technology}

The Lyminge coulter has attracted widespread comment in recent literature as a potentially paradigm-changing find that calls into question the conventional dating of the introduction of the heavy plough in Anglo-Saxon England (Hamerow 2012: 148; Higham \& Ryan 2013: 325-26; Oosthuizen 2013: 65; Williamson 2013: 17-18; Banham \& Faith 2014: 46). Plough-irons were previously conspicuous by their absence from Anglo-Saxon contexts pre-dating the ninth century AD (Astill 1997: 201-202). This negative evidence, combined with the later tenth-eleventh century chronological horizon provided by depictions of heavy ploughs in Late Saxon illuminated manuscripts, has influenced recent interpretations, the most authoritative examination of the subject concluding that "until such is evidenced (C) Antiquity Publications Ltd, 2016 

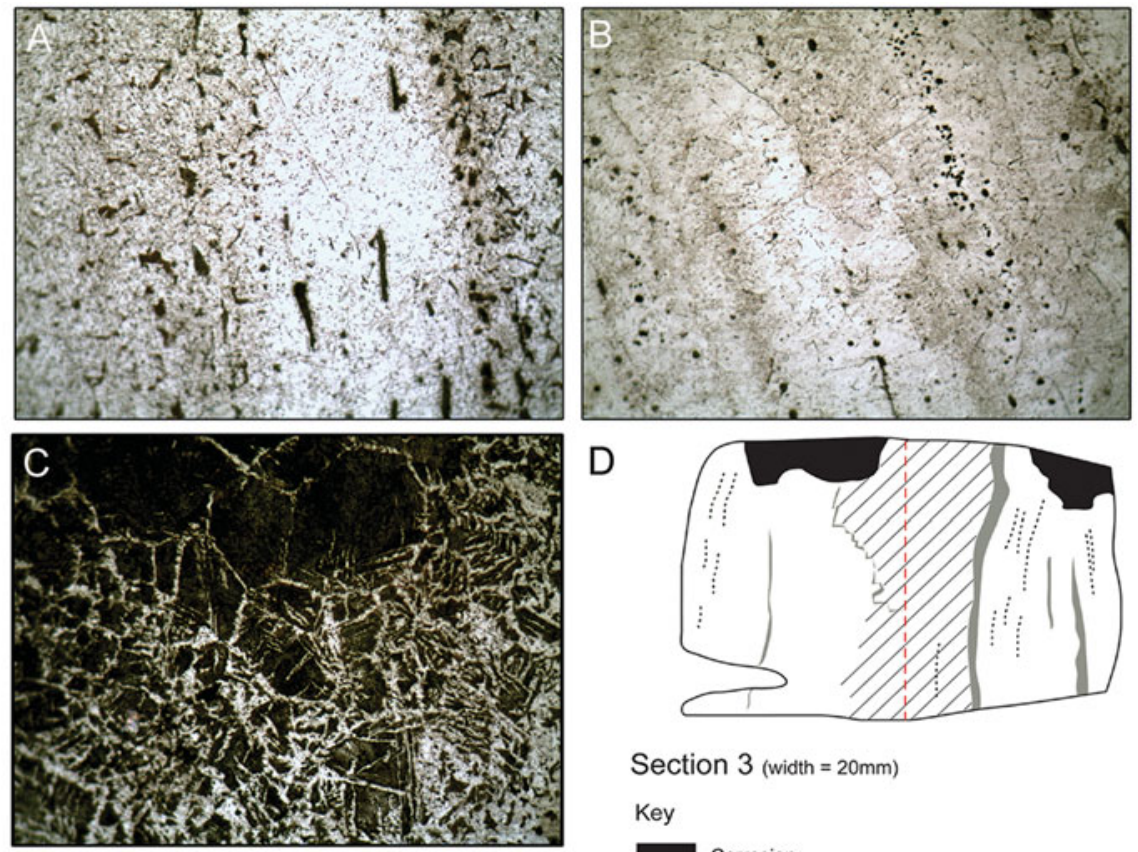

Section 3 (width $=20 \mathrm{~mm}$ )

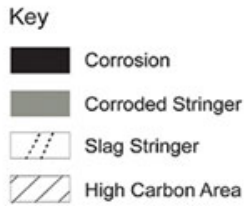

Figure 8. The microstructure of billets 1 and 2 present in metallographic sections 2 and 3, prepared with 3\% Nital (nitric acid in ethanol), with images taken with a reflected light microscope; $\boldsymbol{A}$ shows a central white phosphoric band, flanked by ferritic iron with black non-metallic slag inclusions orientated through section 2; $\boldsymbol{B}$ (the right-hand portion of section 3) shows phosphoric and ferritic banding with black slag inclusions, both at WoF (width of field) =1mm; $\boldsymbol{C}$ is an image from the same section ( $W o F=0.5 \mathrm{~mm})$ showing the edge of high carbon pool $(0.8 \% \mathrm{C}$, top) degrading to a lower carbon zone (bottom); the full microstructure of section 3 is shown in $\boldsymbol{D}$. A description of the microstructures can be found in Table 2.

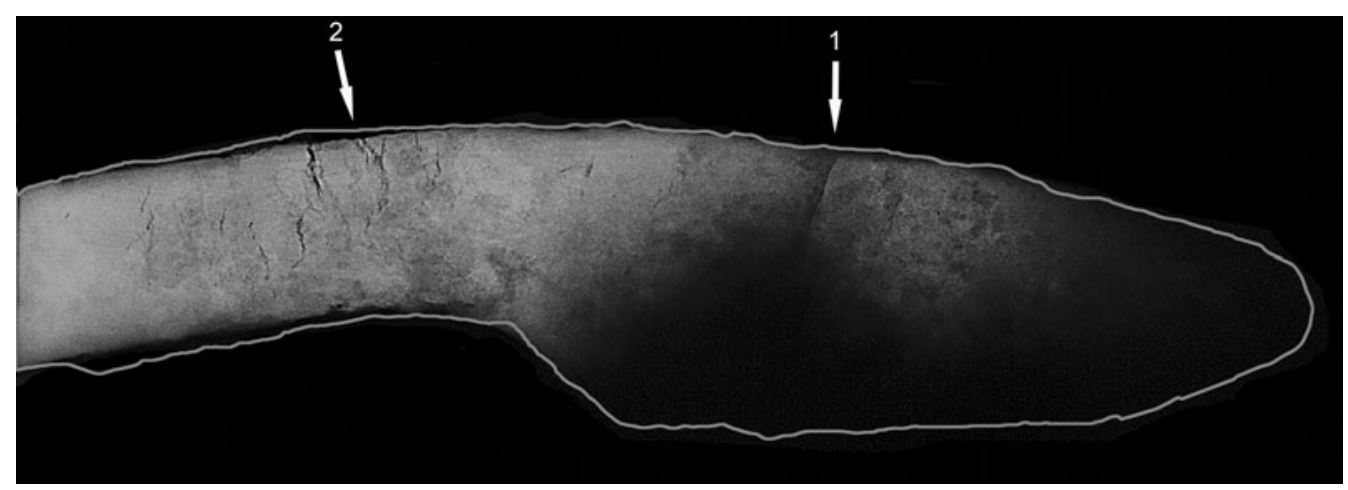

Figure 9. X-radiograph showing stress damage to the shoulder and blade of the coulter; point 1 shows sheering of the weld between billets 1 and 2 and point 2 shows stress cracking surrounding the weld joining billets 2 and 3; taken by the Royal Armouries, AM2165 at 250kV, $5 \mathrm{~mA}, 30$ seconds. 


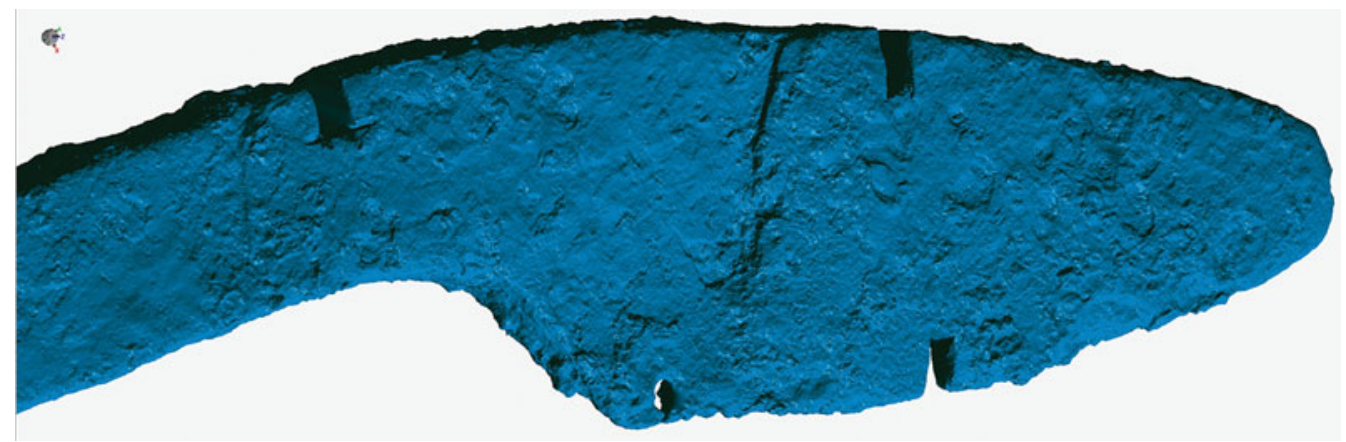

Figure 10. Laser-scanned image showing stress-distortion to the blade and shoulder section of the coulter.

archaeologically before AD 900, the ard [... ] and not the 'heavy plough' [...] should be regarded as the principal cultivating implement of the Anglo-Saxons" (Fowler 2002: 203-204).

Several factors must be taken into account in evaluating whether the Lyminge coulter poses a serious challenge to this orthodoxy. Is the find from a plough or some alternative form of 'coultered' tillage implement (e.g. Comet 1997: 22-23)? Can we extrapolate wider patterns from a single find given clear evidence for the simultaneous use of ard and plough technology in various parts of early medieval north-western Europe (Myrdal 1993: 15359; Zimmermann 1995: 308; Fowler 2002: 184), and the more general distinction that must be made between the inception of a technological innovation and its widespread diffusion (Astill 1997: 195; van der Veen 2010: 2-6)? In our view, the considerable size and weight of the Lyminge coulter — on a par with the largest known archaeological survivals (and with examples attached to extant post-medieval ploughs) — renders alternative technological scenarios improbable. Close consideration of the historical and archaeological context surrounding the find suggests, however, that early use of this technology in AngloSaxon England was probably restricted to Kent, under the influence of continental agrarian practices.

To develop this argument, we must examine the technological implications of the coulter's distinctive perforated blade in its wider north-western European context.

The introduction of the heavy plough into the Frankish empire has been widely regarded as a relatively late development, associated with Carolingian land reforms of the later eighth and ninth centuries AD (e.g. Bloch 1931). This view is predicated on the assumption that the collapse of the Western Roman Empire ushered in centuries of regression in the rural economy and a return to prehistoric modes of production, and with it the widespread reversion to the use of the primitive ard. Recently, this account has been challenged from a range of archaeological perspectives, stimulated by a proliferation of data from excavated rural settlements: far from being a period of regression, the seventh-ninth centuries AD witnessed dynamic and far-reaching innovations in systems of agricultural production across many parts of Europe (Astill 1997; Castillo 2014).

One of the seminal contributions to this reassessment has been an expansive study of plough-irons from dated early medieval contexts across the Frankish empire (Henning (C) Antiquity Publications Ltd, 2016 
2009: 153-58). This analysis points towards early medieval use of the 'swivel plough', a distinct technological variant of the heavy plough - previously regarded to represent a late, post-medieval adaptation - with a moveable mouldboard and 'floating' coulter that could be switched to either side of the ploughshare. In extant examples, in use in some regions until as recently as the nineteenth century, a chain was frequently used to attach the floating coulter to the plough-beam as an added means of security, explaining perforations in archaeological discoveries of the early medieval period.

The Lyminge coulter's place of discovery is consistent with the proposal that Frankish influence lies behind the geographically restricted use of this plough technology in AngloSaxon England. Strong political, dynastic and economic ties were established between the ruling elites of Kent and the Frankish kingdom during the second half of the sixth century, only to intensify with the conversion of the Kentish kingdom to Christianity in AD 597 (Wood 1983). It has been argued that Kent's political ascendancy at this time was closely connected with the importation of foreign luxuries from the Frankish continent (Huggett 1988). The Lyminge coulter suggests that privileged access to foreign agricultural innovations may also have played a part in this process, a claim further supported by the recent discovery from Northfleet, Kent, of the earliest watermill from Anglo-Saxon England (Hardy et al. 2011). Equally significant is Lyminge's role as a focal point of royal and political authority in the regional landscape, evidenced archaeologically by high-status cultural assemblages, conspicuous consumption of animal and other economic resources and a range of specialised crafts, culminating in the construction of a seventh-century 'great hall' complex (Thomas 2013). This attests to major and sustained investment in Lyminge as a place of power, kingship and ceremonial activity: precisely the kind of social milieu where one might expect to find experimentation with novel technology and estate infrastructure geared towards increasing agricultural surplus for on-site consumption.

\section{The deposition of plough-irons: object biography and ritual meanings}

The early medieval era is characterised by the emergence of hybrid devotional practices generated by the interaction of pagan and Christian ideologies (Carver 2003; Pluskowski \& Patrick 2003). One expression of this hybridity was the assimilation of pre-Christian modes of ritual deposition into the pararituals of Christian life (Crawford 2004; Gilchrist 2012: 227-36). An object-biography approach encourages such acts of deposition to be viewed as ritual actions marking the final stage, or 'death', in the social life of the object (Brück 1999; Gosden \& Marshall 1999; Joy 2009; Gilchrist 2012: 11-13). The seemingly deliberate concealment of the Lyminge coulter with the abandonment of a sunken-featured building exemplifies a wider pattern of distinct and unusual depositional treatments characterising the social biography of early medieval plough-irons. We now examine the background to these practices to understand the significance of the Lyminge coulter's distinctive mode of deposition.

Iron hoards are the source of the overwhelming majority of plough-irons from AngloSaxon England, including three of the four known plough coulters (Leahy 2013: tab. 1). The most striking aspect of these collections is their functional diversity, characterised by combinations of agricultural implements, craft-working tools, door and chest furniture, 
weaponry and, less commonly, unworked billets. For this reason, such collections have frequently been interpreted as concealed caches of smith's tools or scrap metal (Leahy 2003: 169-71). More recently, interpretation of these hoards has taken an increasingly nuanced turn, taking into account the fact that many have been recovered either from watery environments characterising much earlier traditions of ritual deposition, or from settlement contexts associated with the closure of significant buildings (Thomas 2008; Lund 2010; Leahy 2013). These contextual associations support the theory that the collections concerned were invested with symbolic meanings linked to the widespread mythologisation of the smith in early medieval societies (e.g. Hinton 2003). Viewed in the light of socially informed interpretations of prehistoric depositional behaviour (e.g. Bradley 1991; Giles 2007), this practice can be understood as a ritual strategy for harnessing or controlling inalienable objects imbued with the supernatural aura and transformative powers of their makers (Lund 2010: 58).

Isolated plough-irons found in connection with early medieval settlements and furnished graves provide a rather different perspective on this theme. For in contrast to collections of iron tools curated by, and thus biographically entwined with, smiths, these individual objects must have entered a wider sphere of social relationships through daily use. It is important to note here that 'use' in an early medieval context included a ritualised setting quite divorced from the everyday activities of agricultural production: the early medieval judicial practice of 'ordeal by fire', whereby accused felons were required to hold or walk over glowing hot irons to establish their innocence. An explicit connection between the fire ordeal and plough-irons, including coulters, is documented in Frankish texts from $\mathrm{AD}$ c. 800 with the earliest mention in English historical sources in the twelfth century (Bartlett 1986: 4-12). But the deposition of plough-irons in Merovingian graves of the sixth-seventh centuries $\mathrm{AD}$, some of which display unusual body positioning characteristic of 'deviant burial', suggests that the practice may have considerably earlier origins (Henning 2007).

Many of the plough-irons recovered from early medieval settlement contexts may also represent traces of ritual actions. This includes two instances of plough shares buried in association with ninth-century funerary chapels forming cult foci within contemporary settlements, one at Mountours in eastern Brittany, and the other at Flixborough, Lincolnshire (Le Gall \& Menez 2008: 18-21; Ottaway 2009: 245; Loveluck 2013: 44-45). It has been suggested that these cases might represent the aftermath of the consecration of sacred Christian sites by ploughing, recalling similar traditions of ritual tillage documented in connection with Bronze Age mortuary contexts (Bradley 2005: 23-28). While this specific practice is unsubstantiated in historical sources, it may be noted that the earliest-recorded Christian consecration rites do appear to have been influenced by long-standing fertility rituals performed within the context of early medieval rural communities (Gittos 2013: 19-49).

A growing number of plough-irons can also be confidently attributed to domestic contexts on early medieval rural settlements, many bearing close comparison with structured foundation or closure deposits seen on later prehistoric and Roman habitations in northern Europe (Brück 1999; Fulford 2001; Bradley 2005). The practice is attested earliest on Roman Iron Age (third-fifth centuries AD) settlements on the Germanic continent, mostly

(C) Antiquity Publications Ltd, 2016 
in connection with sunken-featured buildings (Henning 2014: 341-46), but also recurs in the final century and immediate aftermath of the first millennium AD in the North Sea Zone and Ireland (O'Sullivan 2008; Loveuck 2013: 45). Although the Lyminge coulter is the first example of its type to be discovered in an Anglo-Saxon settlement context, the circumstances of deposition accord very closely with a wider repertoire of 'special deposits' recognised in English settlements of the fifth-seventh centuries AD, the majority of which relate to the closure of sunken-featured buildings (Hamerow 2006).

Early medieval examples of plough-irons buried in settlement contexts can be explained with reference to the longue durée of the ritualisation of domestic life: a process whereby activities such as ploughing, cooking, spinning and weaving were emphasised in performative rituals grounded in concepts of fertility and reproduction metaphorically entwined with the seasonal rhythms of the annual cycle (Bradley 2005). Old English field blessings captured in Late Anglo-Saxon texts help to chart the incorporation of these long-standing practices, including rituals directly associated with ploughing, into an early Christian framework (Banham 2010). Indeed, the horizon of ritual practice documented by the Lyminge coulter and its early medieval analogues not only looks back to the pre-Christian past, but also forward to the Middle Ages, by which time 'Plough Monday', a celebration suffused with plough symbolism and ritual performances, had emerged as one of the major seasonal festivals of the Christian calendar (Hutton 1996: 124-29; Gilchrist 2012: 106-107).

\section{Conclusion}

The Lyminge coulter adds new definition to our understanding of the earliest use of heavy plough technology in Anglo-Saxon England. Its size and distinctive form suggests that a continentally inspired version of the 'swivel plough' was in use in Kent centuries before heavy plough technology is first depicted in Late Saxon manuscript illustrations. Its discovery in what, at the time of its deposition, was the most powerful and outward-looking of the Anglo-Saxon kingdoms, in one of its key political centres, is an important reminder that the adoption of agricultural technology was always a contingent process governed by the receptivity of particular regions, communities and social contexts.

The coulter deserves to be understood as more than simply a missing link in the story of agricultural intensification in Anglo-Saxon England. Our biographical approach has focused on the considerable investment that went into making the Lyminge coulter and the fact that it had sustained major damage and wear during the phase of its life when it was attached to a plough. The circumstances of its deposition can be seen to fit into a consistent pattern of ritual treatments reflected in the find contexts of other plough-irons from early medieval northern Europe. These archaeologically attested practices shed important light on the ritual actions of plough symbolism in an age of religious hybridity and transformation.

\section{Acknowledgements}

The authors would like to thank Lloyd Bosworth, Department of Classical and Archaeological Studies at the University of Kent, and the Royal Armouries, Leeds, for conducting, respectively, the laser scanning and $\mathrm{X}$-radiography of the coulter. The investigative conservation, gap filling after metallography, and the final 


\section{Gabor Thomas et al.}

conservation of the coulter were completed by Libby McCormick and Luciana Carvalho (MSc students in Conservation for Archaeology and Museums) under the supervision of John Merkel at the UCL Institute of Archaeology. We are also indebted to Stuart Laidlaw for providing photographic assistance with Figure 9, and to Simon Maslin for assistance with the preparation of Figures 1 and 2. Gabor Thomas would like to thank Martin Bell, Richard Bradley, Roger Matthews and Peter Fowler for providing critical feedback on a previous draft of this paper. The excavation and analysis upon which this paper is based have been funded by the Arts and Humanities Research Council, the British Academy, the Society of the Antiquaries of London, the Marc Fitch Fund and the Royal Archaeological Institute.

\section{References}

AstiLL, G. 1997. An archaeological approach to the development of agricultural technologies in medieval England, in G. Astill \& J. Langdon (ed.) Medieval farming and technology: 193-223. Leiden: Brill.

BANHAM, D. 2010. The staff of life: cross and blessings in Anglo-Saxon cereal production, in S.L. Keefe, K.L. Jolly \& C.E. Karkov (ed.) Cross and cruciform in the Anglo-Saxon world: studies to honour the memory of Timothy Reuter: 279-318. Morgantown (WV): Sancta Crux. http://dx.doi.org/10.1093/ acprof:oso/9780199207947.001.0001

Banham, D. \& R. Faith. 2014. Anglo-Saxon farms and farming. Oxford: Oxford University Press. http:// dx.doi.org/10.1093/acprof:oso/9780199207947. 001.0001

BARTLETT, R. 1986. Trial by fire and water: the medieval judicial ordeal. Oxford: Clarendon.

BLOCH, M. 1931. Les caractères originaux de l'histoire rurale française. Paris: Librairie Armand Colin.

BRADlEY, R. 1991. The passage of arms. Cambridge: Cambridge University Press.

- 2005. Ritual and domestic life in prehistoric Europe. London: Routledge.

Bronk Ramsey, C. 2009. Bayesian analysis of radiocarbon dates. Radiocarbon 51: 337-60.

BRÜCK, J. 1999. Houses, lifecycles and deposition on Middle Bronze Age settlements in southern England. Proceedings of the Prehistoric Society 65: 145-66. http://dx.doi.org/10.1017/S0079497X00001973

Carver, M. 2003. Northern Europeans negotiate their future, in M. Carver (ed.) The cross goes north: processes of conversion in northern Europe, $A D$ 300-1300: 3-14. Woodbridge: Boydell.

CASTILLO, J.A.Q. 2014. Agrarian archaeology in early medieval Europe. Quaternary International 346: $1-6$. http://dx.doi.org/10.1016/j.quaint.2014.08.007

Comet, G. 1997. Technology and agricultural expansion in the middle ages: the example of France north of the Loire, in G. Astill \& J. Langdon (ed.) Medieval farming and technology: 11-39. Leiden: Brill.

(C) Antiquity Publications Ltd, 2016

CraWford, S. 2004. Votive deposition, religion and the Anglo-Saxon furnished burial rite. World Archaeology 36: 87-102. http://dx.doi.org/10.1080/0043824042000192641

DuBY, G. 1978. Die Landwirtschaft des Mittelalters 900-1500, in C.M. Cipolla (ed.) Europäische Wirtschaftsgeschichte, I: Mittelalter: 111-39. Stuttgart: Schöningh.

FOWLER, P. 2002. Farming in the first millennium AD. Cambridge: Cambridge University Press.

FULFORD, M. 2001. Links with the past: pervasive 'ritual' behaviour in Roman Britain. Britannia 32: 199-218. http://dx.doi.org/10.2307/526956

GiLCHRIST, R. 2012. Medieval life: archaeology and the life course. Woodbridge: Boydell.

GILES, M. 2007. Making metal and forging relations: iron-working in the British Iron Age. Oxford Journal of Archaeology 26: 395-413. http://dx.doi.org/10.1111/j.1468-0092.2007. 00290.x

GiTTOS, H. 2013. Liturgy, architecture, and sacred places in Anglo-Saxon England. Oxford: Oxford University Press. http://dx.doi.org/10.1093/acprof:osobl/ 9780199270903.001 .0001

Gosden, C. \& Y. Marshall. 1999. The cultural biography of objects. World Archaeology 31: 169-78. http://dx.doi.org/10.1080/00438243. 1999.9980439

Hamerow, H. 2006. Special deposits on Anglo-Saxon settlements. Medieval Archaeology 50: 1-30. http://dx.doi.org/10.1179/174581706x124211

- 2012. Rural settlements and society in Anglo-Saxon England. Oxford: Oxford University Press.

Hardy, A., M. Watts \& D. Goodburn. 2011. The mid-Saxon mill at Northfleet, in P. Andrews, E. Biddulph, A. Hardy \& R. Brown (ed.) Settling the Ebbsfleet Valley: high speed I: excavations at Springhead and Northfleet, Kent: the Late Iron Age, Roman, Saxon, and medieval landscape: 307-51. Oxford: Oxford Wessex Archaeology. 


\section{Technology, ritual and Anglo-Saxon agrarian production}

HeNning, J. 2007. HeißEisen der frühen

Rechtsgeschichte: Pfugschare als Grabbeigaben in der Merowinger- und Karolingerzeit, in H. Brink-Kloke \& K.H. Deutmann (ed.) Die Herrschaften von Asseln: Ein frühmittelaterliches Gräberfeld am Dortmunder Hellweg: 109-14. Munchen: Deutscher Kunstverlag.

- 2009. Revolution or relapse? Technology, agriculture and early medieval archaeology in Germanic Central Europe, in J. Ausenda, P. Delogu \& C. Wickham (ed.) The Langobards before the Frankish Conquest: 149-73. Woodbridge: Boydell $\&$ Brewer.

- 2014. Did the 'Agricultural Revolution' go east with Carolingian conquest? Some reflections on early medieval rural economics of the Baiuvarii and Thuringi, in J. Fries-Knoblach \& H. Steuer with J. Hines (ed.) The Baiuvarii and Thuringi: an ethnographic perspective: 331-60. Woodbridge: Boydell.

Higham, N.J. \& M.J. Ryan. 2013. The Anglo-Saxon world. New Haven (CT) \& London: Yale University Press.

Hinton, D.A. 2003. Anglo-Saxon smiths and myths, in D. Scragg (ed.) Textual and material culture in Anglo-Saxon England: 261-82. Cambridge: D.S. Brewer.

Hope-TaYlor, B. 1977. Yeavering: an Anglo-British centre of early Northumbria. London: Her Majesty's Stationery Office.

HugGETT, J.W. 1988. Imported grave goods and the early Anglo-Saxon economy. Medieval Archaeology 32: 63-96.

HutTON, R. 1996. The stations of the sun: a history of the ritual year in Britain. Oxford: Oxford University Press. http://dx.doi.org/10.1093/acprof:oso/ 9780198205708.001.0001

JONES, A. 2002. Archaeological theory and scientific practice. Cambridge: Cambridge University Press.

JOY, J. 2009. Reinvigorating object biography: reproducing the drama of object lives. World Archaeology 41: 540-56. http://dx.doi.org/10.1080/00438240903345530

KLÁPక̌TĚ, J. 1998. Les outils de la preparation du sol au Moyen Âge (à propos des fouilles archéologiques tchèques), in L. Feller, P. Mane \& F. Piponnier (ed.) Le village medieval et son environment: 359-65. Paris: Publications de la Sorbonne.

KLÁP̌̌TĚ, J. \& A.N. JAUBERT. 2007. Rural settlement, in J. Graham-Campbell (ed.) The archaeology of medieval Europe. Volume 1: eighth to twelfth centuries $A D$ : 76-110. Aarhus: Aarhus University Press.
Le Gall, J. \& Y. Menez. 2008. La Chapelle de Saint-Symphorien à Paule, rapport de fouille annuelle 2008. Rennes: Société regional de l'archéologie de Bretagne, L'Unité mixte de recherché, Centre de recherche en archéologie, archéosciences et histoire, and Conseil Généra de Côtes d'Armour.

LeAHY, K. 2003. Anglo-Saxon crafts. Stroud: Tempus.

- 2013. A deposit of early medieval iron objects from Scraptoft, Leicestershire. Medieval Archaeology 57: 223-27. http://dx.doi.org/10.1179/ 0076609713Z.00000000022

LERCHE, G. 1994. Ploughing implements and tillage practices in Denmark from the Viking period to about 1800 experimentally substantiated by Grith Lerche. Herning: Poul Kristensen.

LOVELUCK, C. 2013. Northwest Europe in the early middle ages, c. AD 600-1150: a comparative archaeology. Cambridge: Cambridge University Press. http://dx.doi.org/10.1017/CBO9781139794725

Lund, J. 2010. At the water's edge, in M. Carver, A. Sanmark \& S. Semple (ed.) Signals of belief in early England: 49-66. Oxford: Oxbow.

MCDonnell, G. 1989. Iron and its alloys in the fifth to eleventh centuries AD in England. World Archaeology 20: 373-82. http://dx.doi.org/10.1080/ 00438243.1989.9980079

McDonnell, G., E. Blakelock, S. Rubinson, N. Chabot, A. Daoust \& V. Castagnino. 2012. The iron economy of Wharram Percy, in S. Wrathmell (ed.) A history of Wharram Percy and its neighbours (York University Archaeological Publications 15): 154-62. York: York University, Department of Archaeology.

MYrdal, J. 1993. The agricultural transformation of Sweden, 1000-1300, in G. Astill \& J. Langdon (ed.) Medieval farming and technology: 147-71. Leiden: Brill.

Oosthuizen, S. 2013. Tradition and transformation in Anglo-Saxon England. London: Bloomsbury.

O'Sullivan, A. 2008. Early medieval houses in Ireland: social identity and dwelling spaces. Peritia 20: 225-56. http://dx.doi.org/10.1484/J.Peri.3.633

OTTAWAY, P. 2009. Agricultural tools, in D.H. Evans \& C. Loveluck (ed.) Life and economy at early medieval Flixborough c. AD 600-1000: 244-45. Oxford: Oxbow.

Pluwskoski, A. \& P. PATRICK. 2003. How do you pray to God? Fragmentation and variety in early medieval Christianity, in M. Carver (ed.) The cross goes north: processes of conversion in northern Europe, AD 300-1300: 29-57. Woodbridge: Boydell.

REES, S.E. 1979. Agricultural implements in prehistoric and Roman Britain (British Archaeological Reports British series 69). Oxford: British Archaeological Reports. 
Reimer, P.J., M.G.L. Baillie, E. Bard, A. Bayliss, J.W. BECK, P.G. BLACKWELL, C. BRONK RAMSEY, C.E. BuCK, G.S. BURR, R.L. EDWARDS, M. FriedRICH, P.M. GROOTES, T.P. GUILDERSON, I. Hajdas, T.J. Heaton, A.G. HogG,

K.A. Hughen, K.F. Kaiser, B. Kromer, F.G. McCormac, S.W. MANNING, R.W. ReImer, D.A. Richards, J.R. SOUTHON, S. TAlamo, C.S.M. Turney, J. van der Plicht \& C.E. WeYHENMEYER. 2009. IntCal09 and Marine09 radiocarbon age calibration curves $0-50,000$ years cal BP. Radiocarbon 51: 1111-50.

http://dx.doi.org/10.2458/azu_js_rc.55.16947

Stuiver, M. \& P.J. Reimer. 1986. A computer programme for radiocarbon age calculation. Radiocarbon 28: 1022-30.

ThOmAs, G. 2008. The symbolic lives of Late Anglo-Saxon settlements: a cellared structure and iron hoard from Bishopstone, East Sussex. The Archaeological Journal 165: 334-98.

http://dx.doi.org/10.1080/00665983.2008. 11020749

- 2013. Life before the minster: the social dynamics of monastic foundation at Anglo-Saxon Lyminge, Kent. The Antiquaries Journal 93: 109-45.

http://dx.doi.org/10.1017/S0003581513000206
Thomas, G. \& A. KNox. 2012. A window on Christianisation: transformation at Anglo-Saxon Lyminge, Kent, England. Antiquity 87(334): Project Gallery. Available at: http://antiquity.ac.uk/projgall/thomas334/ (accessed 8 February 2016).

TIPPER, J. 2004. The Grubenhaus in Anglo-Saxon England. Yedingham: Landscape Research Centre.

Tylecote, R.F. \& B.J.J. Gilmour. 1986. The metallography of early ferrous edge tools and edged weapons (British Archaeological Reports British series 155). Oxford: British Archaeological Reports.

VAN DER VEEN, M. 2010. Agricultural innovation: invention and adoption or change and adaptation? World Archaeology 42: 1-12. http://dx.doi.org/10.1080/00438240903429649

WHITE, L. 1962. Medieval technology and social change. Oxford: Clarendon.

Williamson, T. 2013. Environment, society and landscape in early medieval England. Woodbridge: Boydell.

Wood, I.N. 1983. The Merovingian North Sea. Alingsas: Viktoria.

ZimmermanN, W.H. 1995. Ackerbau in ur- und frühgeschichtlicher Zeit auf der Geest und in der Marsch, in H.E. Dannenberg \& H.J. Schulze (ed.) Geschichte des Landes zwischen Elbe und Weser, Band 1: 289-315. Stade: Ditzen Druck.

Received: 17 March 2015; Accepted: 14 May 2015; Revised: 9 June 2015

(C) Antiquity Publications Ltd, 2016 